\title{
Examination of zinc adsorption capacity of soils treated with different pyrolysis products
}

\author{
Gabriella RÉTHÁTI ${ }^{1 *}$ Adrienn VEJZER, ${ }^{1}$ Barbara SIMON, ${ }^{1}$ \\ Ramadan BENJARED, ${ }^{1}$ György FÜLEKY ${ }^{1}$ \\ Szent István University, Institute of Environmental Science, \\ Department of Soil Science and Agricultural Chemistry, H-2103 Gödöllö, Páter K. u. 1. \\ rethati.gabriella@mkk.szie.hu (*corresponding author)
}

Manuscript received 07. 21. 2014; revised 07. 30. 2014; accepted; 15. 08. 2014

\begin{abstract}
Organic matter input into soils is essential regarding agricultural, environmental and soil science aspects as well. However, the application of the pyrolysed forms of biochars and materials with different organic matter content gained more attention in order to decrease the emission of the green house gases $\left(\mathrm{CO}_{2}, \mathrm{~N}_{2} \mathrm{O}\right)$ from the soil. During pyrolysis, the materials containing high organic matter (biomass-originated organic matter) are heated in oxygen-free (or limited amount of oxygen) environment. As a result, the solid phase, which remains after eliminating the gases and liquid phase, is more stable compared to the original product, it cannot be mineralized easily in the soil and its utilization is more beneficial in terms of climatic aspects. Furthermore, it can improve soil structure and it can retain soil moisture and cations in the topsoil for long periods of time, which is very important for plants. In our experiment, the effects of biochar and bone char were examined on soils by zinc adsorption experiments. Based on our experiments, we concluded that the pyrolysis products can have significant $\mathrm{Zn}$ adsorption capacity compared to the soil. Bone ash can adsorb more $\mathrm{Zn}$ than the charcoal product. The $\mathrm{Zn}$ adsorption capacity of soils treated by pyrolysis products can be described by Langmuir adsorption isotherms. However, based on the amount of pyrolysis products, one or two term Langmuir isotherm fits well on the experiment data, which depends on the time the pyrolysis product has spent in the soil.
\end{abstract}

Keywords: biochar, bone char, Zn adsorption

\section{Introduction}

The pyrolysed biomass products have high carbon content and their chemical structures differ greatly. Thus, the weakly charred organic materials, such as the 
biochar and the soot, also belong to this group [1]. Depending on the temperature of the pyrolysis, different structural changes occur in the organic macromolecules. By the effect of the lower temperature, the chemically bound water will leave; then, as the temperature increases, the functional groups, the amount of oxygen and hydrogen will decrease, which might result in an aromatic and polyaromatic structure [2]. This type of organic matter can resist the mineralization processes in the soil for a long period of time (even for 100 years); thus, it decreases the amount of greenhouse gases $\left(\mathrm{CO}_{2}, \mathrm{~N}_{2} \mathrm{O}\right)$, leaving the soil in the atmosphere. Their role is essential from climatic aspects, but they also improve soil structure, moisture and the nutrient holding capacity of soils.

In our experiments, we compared the $\mathrm{Zn}$ retention capacity of two types of pyrolysed organic substances (biochar, bone char), and we examined the effect of incubation on the $\mathrm{Zn}$ retention capacity in soil-biochar systems with different composition.

\section{Materials and methods}

\section{Incubation}

The soil that was used in our experiment (Tab. 1) was mixed with $0,1,2.5,5$ and $10 \%$ pyrolysed products (biochar, bone char). Soil moisture was adjusted by adding distilled water to $50 \%$ of field capacity; then it was incubated for two weeks. After this, the samples were dried and sieved $(2 \mathrm{~mm})$, and adsorption experiments were carried out.

Tab. 1. Parameters of the test soil (brown forest soil, Gödöllö)

\begin{tabular}{|c|c|c|c|c|c|c|}
\hline $\mathbf{K}_{\mathbf{A}}$ & $\begin{array}{c}\mathrm{pH} \\
\text { (KCl) }\end{array}$ & $\begin{array}{c}\mathrm{pH} \\
\left(\mathrm{H}_{2} \mathrm{O}\right)\end{array}$ & $\begin{array}{c}\text { Humus } \\
\%\end{array}$ & $\begin{array}{l}\text { Total } \\
\text { C\% }\end{array}$ & $\begin{array}{c}\text { Total } \\
\text { N\% }\end{array}$ & $\begin{array}{c}\mathrm{AL}-\mathrm{P}_{2} \mathrm{O}_{5} \\
\mathrm{mg} / \mathrm{kg}\end{array}$ \\
\hline 25 & 4.9 & 5.2 & 1 & 0.58 & 0.58 & 33 \\
\hline
\end{tabular}

Tab. 2. Parameters of the pyrolysed products

\begin{tabular}{|c|c|c|c|c|c|c|c|c|c|}
\hline & $\overline{2}$ & 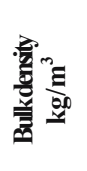 & 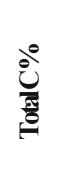 & 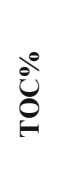 & $\frac{\stackrel{\circ}{Z}}{\stackrel{\mathrm{z}}{\mathrm{g}}}$ & 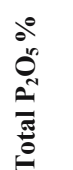 & $\begin{array}{l}d^{\circ} \\
0^{n} \\
\hat{L}^{n} \\
\frac{1}{4}\end{array}$ & 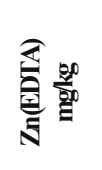 & 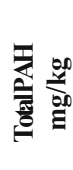 \\
\hline Biochar & 8.3 & 360 & 80 & 70 & 0.7 & 0.2 & 0.05 & 73.8 & 4.8 \\
\hline Bone char & 7.5 & 320 & 10 & 9 & 1.8 & 31 & 5.63 & 3.6 & 0.4 \\
\hline
\end{tabular}




\section{Adsorption Experiment}

One gram of the above-mentioned treated soil samples and the pyrolysis products were placed in centrifuge tubes. They were mixed with $\mathrm{Zn}$ solution (shaking solution) with different concentrations $(0,25,50,75,100,200,250,500$, $600,750,1000 \mathrm{mg} \mathrm{dm}^{-3}$ ) in a ratio of $1 \mathrm{~g}$ to $10 \mathrm{~cm}^{3}$ during 12 hours in rotary shaker at constant temperature $\left(20 \pm 1^{\circ} \mathrm{C}\right)$. After completing the shaking, centrifugation $(5,000 \mathrm{rpm}, 5$ minutes) and filtration were carried out; then, with proper dilution, the $\mathrm{Zn}$ concentrations of the filtrate (hereinafter: equilibrium solutions) were measured by Perkin Elmer 303 AA spectrophotometer. Knowing the concentration of the shaking and the equilibrium solution, we calculated the amount of adsorbed $\mathrm{Zn}$ on the solid phase. Then we illustrated the amount of adsorbed $\mathrm{Zn}\left(\mathrm{mg} \mathrm{kg}^{-1}\right)$ as a function of the concentration of the equilibrium solution. We fit the Langmuir adsorption isotherm onto the obtained experimental points, which mathematical form is the following:

$$
q=\frac{A \cdot k \cdot c}{1+k \cdot c}+b \quad \begin{aligned}
& \mathbf{q}=\text { the amount of } \mathrm{Zn} \text { adsorbed by the soil }(\mathrm{mg} / \mathrm{kg}) \\
& \mathbf{A}=\text { maximum amount of } \mathrm{Zn} \text { that can be adsorbed by the soil } \\
& \mathbf{k}=\text { equilibrium constant of adsorption }\left(\mathrm{dm}^{3} / \mathrm{mg}\right) \\
& \mathbf{c}=\text { Zn concentration of equilibrium solution }\left(\mathrm{mg} / \mathrm{dm}^{3}\right) \\
& \mathbf{b}=\text { constant }(\mathrm{mg} / \mathrm{kg})
\end{aligned}
$$

\section{Results and discussions}

The bone char adsorbed a large amount of Zn (Fig. 1), which can be explained by the high phosphate content of the bone char (Tab. 2). In this case, the $\mathrm{Zn}$ is not adsorbed in an exchangeable form, but precipitation occurred, since poorly-soluble Zn-phosphates were produced.

This is also proved by the equilibrium constant $(\mathrm{k})$ of the process and the steepness of the isotherm curve calculated in different points and the buffering capacity values as well (Tab. 3).

Thus, the bone char mixed into the soil significantly increased its $\mathrm{Zn}$ retention capacity; even when $5 \%$ bone char was mixed in, it doubled the maximum amount of $\mathrm{Zn}$ that can be retained. 


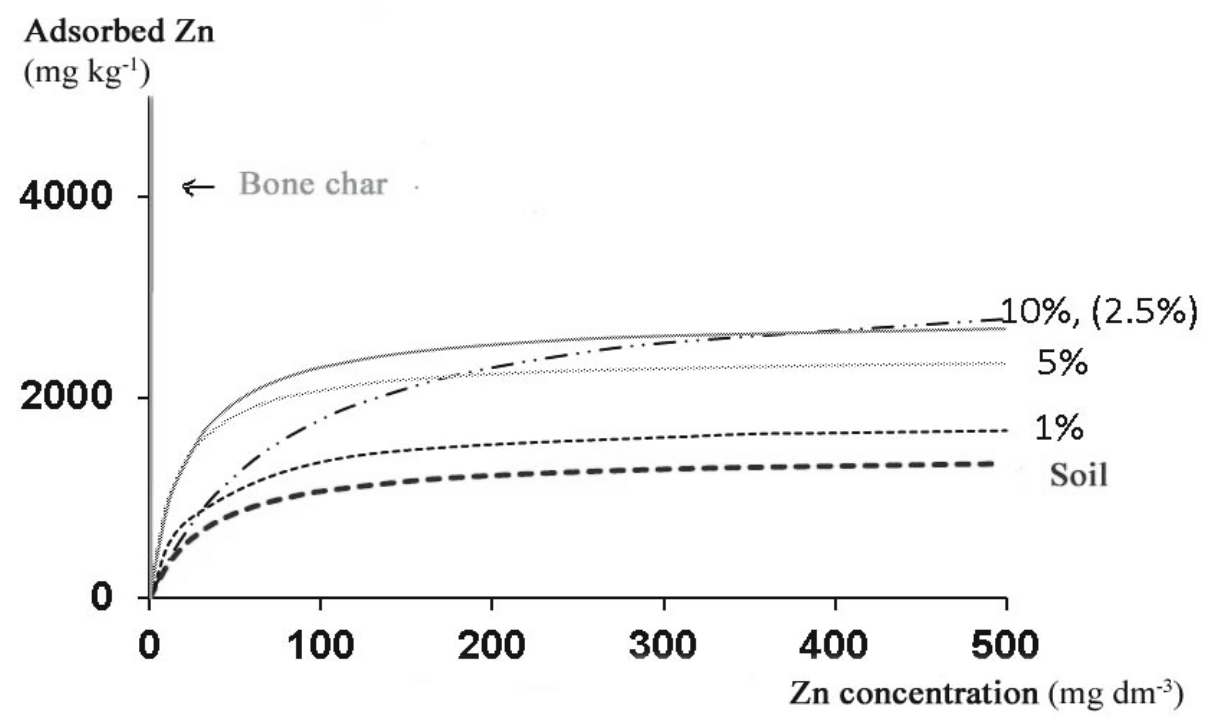

Fig. 1. Zn adsorption capacity of bone char and soils treated with bone char (Langmuir isotherms)

The $\mathrm{Zn}$ retention capacity of biochar and soils treated with biochar was significantly lower compared to the bone char. The maximum amount of $\mathrm{Zn}$ that the soil can retain is nearly seven times higher than the amount the biochar can retain. This is probably due to the fact that chemical changes occurred within the structure of the biochar during the pyrolysis, which destroyed its cation retention capacity.

Tab. 3. Parameters of the Langmuir isotherms of bone char and soils treated with bone char

\begin{tabular}{lcccccc}
\hline & \multicolumn{2}{c}{$\begin{array}{c}\text { Langmuir isotherm } \\
\text { parameters }\end{array}$} & \multicolumn{5}{c}{$\begin{array}{c}\text { Buffering capacity } \\
\left(\mathrm{dm}^{3} / \mathrm{kg}\right)\end{array}$} \\
\hline & $\begin{array}{c}\mathbf{A} \\
\mathbf{m g} / \mathbf{k g}\end{array}$ & $\begin{array}{c}\mathbf{k} \\
\mathbf{d m}^{\mathbf{3}} / \mathbf{m g}\end{array}$ & $\mathbf{0}$ & $\mathbf{0 . 1}$ & $\mathbf{1}$ & $\mathbf{1 0}$ \\
\hline Bone char & 20193 & 0.7768 & 15688 & 13508 & 4968.8 & 204.0 \\
Soil & 1378 & 0.0290 & 41.7 & 41.4 & 39.3 & 25.0 \\
$\mathbf{1 \%}$ bone char & 1768 & 0.0337 & 59.7 & 59.3 & 55.9 & 33.4 \\
$\mathbf{2 , 5 \%}$ bone char & 3236 & 0.0120 & 39.6 & 39.5 & 38.7 & 31.4 \\
$\mathbf{5 \%}$ bone char & 2416 & 0.0604 & 146.1 & 144.4 & 129.9 & 56.7 \\
$\mathbf{1 0 \%}$ bone char & 2804 & 0.0460 & 129.2 & 128.0 & 118.06 & 60.5 \\
\hline
\end{tabular}


Probably, hydrophobic, aromatic structures were formed which are able to adsorb only a few cations. It is interesting, however, that when this material was mixed into the soil and was shortly incubated, the $\mathrm{Zn}$ retention capacity increased.

When $5 \%$ was mixed, the maximum amount of $\mathrm{Zn}$ that can be retained doubled. This phenomenon is probably due to the activated biological processes in the soil in such a short time.

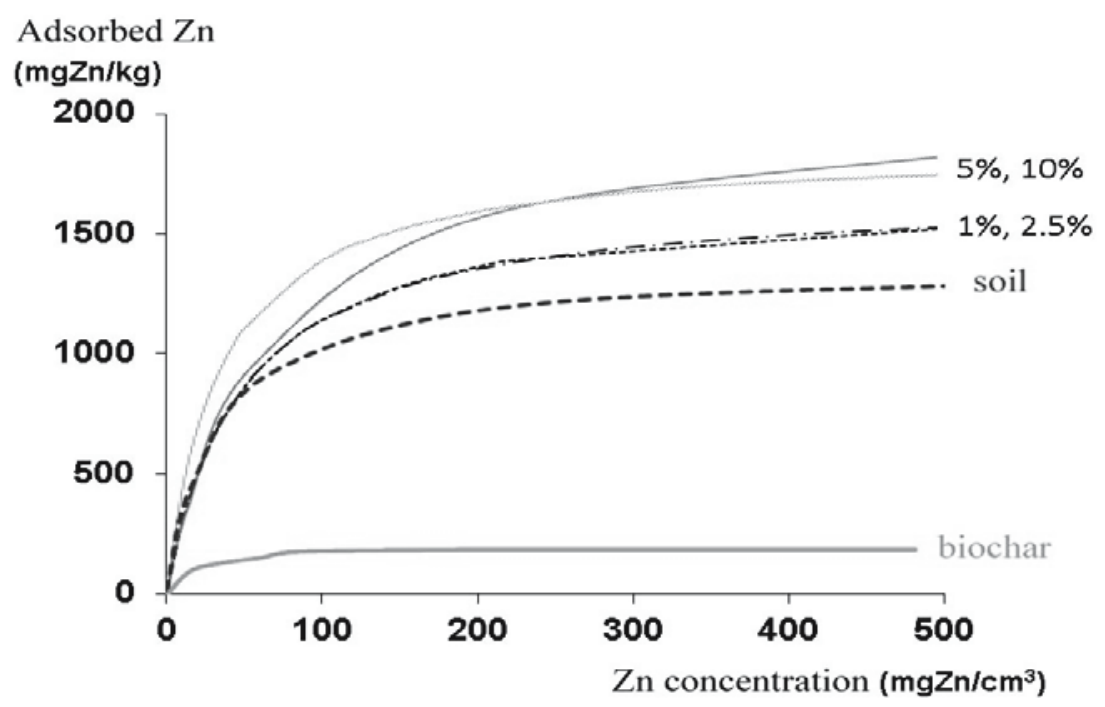

Fig. 2. $\mathrm{Zn}$ adsorption capacity of biochar and soils treated with biochar (Langmuir isotherms)

Tab. 4. Parameters of the Langmuir isotherms of biochar and soils treated with biochar

\begin{tabular}{lcccccc}
\hline & \multicolumn{2}{c}{$\begin{array}{c}\text { Langmuir isotherm } \\
\text { parameters }\end{array}$} & \multicolumn{4}{c}{$\begin{array}{c}\text { Buffering capacity } \\
\left(\mathrm{dm}^{3} / \mathrm{kg}\right)\end{array}$} \\
\hline & $\begin{array}{c}\mathbf{A} \\
\mathrm{mg} / \mathrm{kg}\end{array}$ & $\begin{array}{c}\mathbf{k} \\
\mathrm{dm} / \mathrm{mg}\end{array}$ & $\mathbf{0}$ & $\mathbf{0 , 1}$ & $\mathbf{1}$ & $\mathbf{1 0}$ \\
\hline Biochar & 197.2 & 0.0601 & 11.9 & 11.7 & 10.5 & 4.6 \\
Soil & 1378 & 0.0300 & 41.4 & 41.1 & 39 & 24.5 \\
$\mathbf{1 \% \text { biochar }}$ & 1689 & 0.0208 & 35.2 & 35.0 & 33.8 & 24.1 \\
$\mathbf{2 , 5 \%}$ biochar & 1668 & 0.0215 & 35.8 & 35.7 & 34.4 & 24.3 \\
$\mathbf{5 \%}$ biochar & 2083 & 0.0150 & 31.3 & 31.2 & 30.4 & 23.7 \\
$\mathbf{1 0 \%}$ biochar & 1867 & 0.0287 & 53.6 & 53.3 & 50.7 & 32.4 \\
\hline
\end{tabular}




\section{Conclusions}

The soil microorganisms attach onto these organic substances that have very high surface area and they change their structure during their metabolism. Functional groups that are able to adsorb cations are formed especially on the edges, which are easily accessible.

This is the reason why the pyrolysed organic substances that are able to resist mineralization and sometimes contain toxic material (PAHs) can change into a harmless and useful soil component [3].

\section{Acknowledgements}

This research was funded by TÁMOP-4.2.2.A-11/1/KONV-2012-0015 Project.

\section{References}

[1] Masiello, C. A. (2004), New direction in black carbon organic geochemistry. Marine Chemistry 92, 201-213.

[2] Knicker, H. (2011), Pyrogenic organic matter in soil: Its origin and occurrence, its chemistry and survival in soil environments. Quaternary International 243, 251-263.

[3] Haritash, A. K., Kaushik, C. P. (2009), Biodegradation aspects of polycyclic aromatic hydrocarbons (PAHs): A review. Journal of Hazardaous Matematics 169, 1-15. 